\title{
Tercentenary of the University of Utrecht
}

$\mathrm{O}^{\mathrm{N}}$ June 22-24, a brilliant sun shone on the ancient and famous city of Utrecht, thronged with students and visitors from many lands and gaily decorated with the national flag of Holland and the colours of all the Faculties. The occasion was the celebration of three hundred years of the University's existence. To Utrecht had come the representatives of most of the universities and learned academies of the world, to pay homage and do honour to her ancient and distinguished university. Amidst the scarlet gowns and many coloured hoods of the professors and academicians flashed the white plumes of the horses and the gay cockades of the splendid coachmen of the students' carriages, for to Utrecht had also come the representatives of the students" "senates" from all the universities of Holland, and the associations and clubs of old University of Utrecht men from every part of the country. In this land won by brave men from the sea, where freedom dwells and learning flourishes, all had met to place another milestone on the long road of civilization, wherewith to mark the completion of the third century of a great university's beneficent life.

During the forenoon of Monday, June 22, the associations and clubs of former members of the University came with their banners in a procession from the station, whilst a great carillon pealed and thundered from the thirteenth century tower of the Cathedral Church. In the afternoon, gifts were presented to the University. At eight o'clock in the evening, the foreign delegates, representing universities and learned academies and societies, were received by the Council and Senate in the great Hall of the University, while at nine o'clock the municipality of Utrecht held a reception in the rooms and beautiful garden of the Municipal Art Gallery.

Serious business began on Tuesday, June 23. In the morning the delegates, in academic robes and decorations, were received by the University in the Church of St. Peter. Addresses of welcome were delivered by Dr. S. Jacob, the President of the Council, and Prof. C. H. Vollgraff, the Rector Magnificus. Speeches of congratulation and thanks were then made by Prof. J. Huizinga, of the University of Leyden, and by several foreign delegates, including Dr. Clarke, of the University of Oxford. The University hymn, "In Babylonia", was played on the viola, with organ accompaniment, by Mrs. Vogelsang. As the name of each delegate was called, he came forward and presented an address of congratulation to the President and the Rector. Then the members of Council, the professors of the University of Utrecht and the foreign delegates walked in procession from the Church of St. Peter to the Cathedral Church, where lunch was provided in the cloisters and the beautiful old cloister garden. Among the other English delegates present may be mentioned Prof. G. Barger (representing the University of Edinburgh), Prof. F. G. Donnan (representing the Royal Society and the University of London), and Prof. D'Arcy Thompson (representing the Royal Society of Edinburgh and the University of St. Andrews).
After lunch, the great procession of professors and delegates walked through the streets of Utrecht, which were thronged by enormous crowds of citizens and guarded by cordons of police. This brilliant and most impressive scene was watched by the Queen of Holland and the Princess Juliana. The procession returned by a different route to the Cathedral Church, where a solemn service of commemoration was held in the presence of the Queen and the Princess, and a great gathering of invited guests, including many high officers of the army and navy and high officials of the State. After some of the beautiful organ music of Bach, addresses were delivered by the President of the Council and the Rector Magnificus, the latter giving a long account of the struggle of Western civilization for freedom of learning and liberal government. Then came a very interesting ceremony, the presentation of the first gold medal of honour of the University to the Queen, to which Her Majesty made a suitable reply of thanks. After some more organ music, a short and eloquent address was delivered by His Excellency the Minister of Education, Art and Science. The proceedings were concluded by the ceremony of attaching the third centenary ring to the pole of the great banner of the University.

After the commemoration service, a number of foreign delegates were presented to the Queen, and as the great procession again filed out of the Cathedral Church, a carillon was played by J. A. H. Wagenaar.

In the evening, a banquet was given by the Senate of the University, at which many delegates made speeches of congratulation and thanks. After the banquet the guests were taken by bus to a wonderful open-air performance by members of the Students' Associations. This was a dramatic pageant entitled "De Groote Geus" (The Great Vagabond). The façade of a great castle had been erected in a large meadow, representing the stronghold of a Spanish noble. In front of this the peasants and citizens held a market fair. Then came the "Groote Geus"the Dutch Tilleulenspiegel-with his jesters and his jests, to amuse the people and by sarcastic innuendo to arouse them from their bondage. Their anger grew, but Spanish horsemen and men-at-arms poured from the castle gates to quell them. Finally, the Hidalgo with his chatelaine and retinue came out to witness a masque prepared by Tilleulenspiegel. But the people saw what he meant-it was a masquerade of the "Fat- and swollen-headed overlords". In a burst of rage and anger, they stormed and burnt the castle. The drama thus represented the struggle of the Netherlands for freedom from the Spanish yoke. It was a fine performance, played by something like three hundred students, with elegant costumes and elaborate flood-lighting effects. High praise must be accorded, not only to the author, producer and director, but also to the excellent acting and speaking of Tilleulenspiegel, who had a very heavy part. A special and very enjoyable feature of the pageant was the dramatic music, which was played from behind the façade by the municipal orchestra. This music was specially composed for the occasion by Dr. H. E. Enthoven. 
The forenoon of Wednesday, June 24, was taken up by the conferring of honorary degrees on a number of delegates in the Great Hall of the University. Among those who were thus honoured may be mentioned Sir Henry Dale, Prof. Herbert Freundlich (University College, London), and Dr. Clarke (University of Oxford). At midday the delegates and their ladies were entertained to lunch in the cloisters and cloister garden of the Cathedral Church, after which they witnessed the march past the University of the students' "Masquerade". This was a dramatic procession of pikemen, mounted knights, etc., of which the special feature was the "Prince of Orange" and his retinue.

In the afternoon, there was a very enjoyable excursion (by autobus) into the province of Utrecht, including a visit to Hilversum and its new town hall (a fine building in the modern unadorned style) and tea in the park of the Chateau Deynselburg, given by Madame and Dr. S. Jacob. On returning to Utrecht, the guests paid homage to the "Prince of Orange", who held a Court.

The day concluded with a gala concert in the Tivoli Concert Hall, conducted by the famous Willem Mengelberg. The programme was: Sol Justitiae: a hymn dedicated to the University of Utrecht on the occasion of the third centenary (composed by Dr. H. E. Enthoven); Piet Hein : a Dutch rhapsody (composed by Dr. P. G. van Anrooy); Overture to the "Taming of the Shrew" (composed by Dr. Joh. Wagenaar); Beethoven's Fifth Symphony.

The music was well played by the municipal orchestra under the spirited leadership of Mengelberg. An amusing incident was the arrival of the "Prince of Orange" and his retinue. Even the great Mengelberg had to come down from his rostrum and pay homage !

Thus ended three wonderful days of lavish Dutch hospitality, academic ceremony and students' pageantry. As if in remembrance of the University motto, Sol Justitiae, illustra nos, the sun shone brightly on the gay scene of scarlet gowns, whiteplumed horses, knights on horseback and the great Prince of Orange. The professors of the University amply sustained the honour of their city and their country in offering very kind private hospitality to many of the invited guests.

It was a great demonstration of the universality of learning, of the brotherhood of truth and freedom. As one stood in the peaceful cloister garden and listened to the carillons from the ancient tower, the message of a noble civilization resounded in one's ears. One was glad to feel that Holland had kept the sweet music of her old carillons and in the benign tolerance of a greater humanity had won the freedom of her soul.

F. G. Donnan.

\section{Fractures in Metals and Brittle Materials}

\begin{abstract}
A
DISCUSSION on "Fractures in Metals and Society on Thursday, June 11. Many points of importance were brought out in this interesting discussion, and it is perhaps difficult in the small space of a general article to do justice to them.

In introducing the subject, Dr. H. J. Gough presented a review of the present position of knowledge in regard to the understanding of the mechanism of failure. As regards metals, he holds that in view of their essentially crystalline structure the required physical explanation must be in terms of atomic structure before any real progress in ideas can be achieved. Stripped of non-essentials, the problem is that of obtaining an understanding of plastic deformation and a realization of the exact conditions under which a crack is formed. He emphasized the disability of not having available a satisfactory conception of the laws of cohesion in the metallic state, and the extreme value of any new contribution in this direction. Elasticity is an expected property in a metallic crystalline aggregate, but plasticity is a property which is extremely difficult, at the present time, to understand.

The study of single crystals is very helpful since the processes of deformation and fracture are characteristics associated with the crystal structure, and effects in erystal aggregates are modifications of the effects occurring in single crystals. The geometrical aspects of deformation are established, but give no information on the mechanism of fracture. While stressing the fact that the characteristies of deformation and fracture are probably capable of explanation in terms of single crystals, it must be remembered that the strength of polycrystalline aggregates depends to some extent on crystal size,
\end{abstract}

so that an understanding of the part played by the crystal boundaries is a very important factor in the solution of the whole problem. No established explanation has yet been provided in regard to workhardening, strain hysteresis, twinning and the process of conversion of strain energy indefinitely into heat energy.

Assuming that the mechanism of fracture is essentially a property of the individual crystals, Gough and Wood have described, in a recent paper, an investigation by $\mathrm{X}$-ray methods into the physical system prevailing after different numbers of cycles in fatigue tests. It would appear that at fracture the physical system is the same under all conditions. Under a safe range of stress the damage to the crystal structure is not progressive, but a stable state is reached, whereas under an unsafe range of stress progressive change takes place. The changes in the neighbourhood of the ultimate fatigue crack are characteristic and exactly similar under all unsafe ranges of stress, and in this area the original structure is destroyed and new crystallites formed. This appears to be a definite advance in knowledge.

Prof. G. I. Taylor confined his remarks chiefly to the more precise mathematical theory of internal flaws. If one crystal is deformed, and hardening is produced in the crystal, additional stresses are im. posed on the surrounding crystals, which therefore tend to become deformed. In steel at the yield point the stress is reduced on deformation. In this case the deformation tends to proceed in the same crystal and an irregular deformation results.

If the material has internal flaws-such as might be represented by small spherical and ellipsoidal cavities - the stresses acting locally are increased. Failure under these local stresses would be expected 